\title{
ISLAMIC ECOLOGICAL CULTURE: INTRUMEN UNTUK MEMBENTUK PERILAKU HIDUP BERSIH DAN SEHAT
}

\author{
Muntaha ${ }^{1^{*}}$ \\ ${ }^{1}$ STIKES Widyagama Husada \\ Corresponding author: \\ Muntaha \\ STIKES Widyagama Husada \\ Email: muntaha@widyagamahusada.ac.id
}

\section{Article Info:}

Dikirim: 23, Agustus 2020

Ditinjau: 8, September 2020

Diterima: 11, November 2020

DOI:

https://doi.org/10.33475/jikmh

\begin{abstract}
Islamic education as an ideological superstructure of Muslim students should be able to become a crater of regeneration in order to form a clean and healthy living behaviors. The fact is, there are still many students in Madrasah who still behave otherwise. This research seeks to explore and describe the formation of ecological culture of students of Madrasah Tsanawiyah, therefore the ecological culture can be used as an instrument in order to form clean and healthy behavior. The method used in this research is a case study. Namely, to deeply the success of MTsN 1 Malang in order to form ecological culture of its students. The results showed that MTsN 1 Malang succeeded in forming a Clean and Healthy Behavior of its students through ecological culture. This ecological culture is formed through the inculcation of tauhid values, through the Integrated Islamic Religious Education curriculum, habituation, Uswatun Hasanah, a joint movement in the form of an Environmental Ambassador and supported by the Madrasah environment as a laboratory. With this ecological culture the behavior of students who are aware of cleanliness and healthy living can be formed well.
\end{abstract}

Keywords: Ecological Culture; Tawheed; Uswatun Hasanah

\begin{abstract}
Abstrak
Pendidikan Islam sebagai suprastruktur idiologis siswa muslim mestinya mampu menjadi kawah candradimuka dalam membentuk perilaku hidup bersih dan sehat. Faktanya masih banyak siswa di Madrasah yang masih berperilkau sebaliknya.Penelitian ini hendak menggali dan mendeskripsikan pembentukan budaya ekologis siswa Madrasah Tingkat Tsanawiyah, sehingga budaya ekologis tersebut dapat dijadikan sebagai instrumen pembentuk Perilaku Hidup Bersih dan Sehat. Metode yang digunakan dalam penelitian ini adalah studi kasus. Yakni mendeskripsikan secara mendalam tentang keberhasilan MTsN 1 Malang dalam membentuk budya ekologis siswanya. Hasil penelitian menunjukkan bahwa MTsN 1 Malang berhasil membangun Perilaku Hidup Bersih dan Sehat peserta didiknya melalui budaya ekologis. Budaya ekologis tersebut dibentuk melalui penanaman nilai tauhid, melalui kurikulum Pendidikan Agama Islam Intergratif, pembiasaan, Uswatun Hasanah, gerakan bersama dalam wujud Duta Lingkungan dan didukung dengan lingkungan Madrasah sebagai laboratorium. Dengan budaya ekologis tersebut perilaku siswa yang sadar akan kebersihan dan hidup sehat dapat terbentuk dengan baik
\end{abstract}

Kata Kunci: Budaya Ekologis; Tauhid; Uswatun Hasanah 


\section{PENDAHULUAN}

Umat Islam meyakini bahwa Islam mengajarkan mengenai lingkungan dan memberikan panduan mengenai praktek-praktek yang baik tentang lingkungan termasuk didalamnya tentang Perilaku Hidup Bersih dan Sehat (PHBS). Sebagaimana digambarkan dalam Al-Qur'an (QS.2:222) bahwasannya Allah mendidik umatnya untuk menjaga kebersihan, karena Allah menyukai orang-orang yang mensucikan diri. Dengan mensucikan diri dan menjaga kebersihan akan menciptakan lingkungan yang sehat dan hidup yang bersih (Anam, 2016).

Namun demikian secara faktual ajaran Islam tersebut belum sejalan dengan sikap keseharian sebagian besar umat Islam, yang tampak saat ini adalah budaya yang masih belum mencerminkan nilai-nilai Islam yang ramah lingkungan dan cinta terhadap kebersihan. Hal ini dapat diamati dari beberapa hal, diantaranya pemahaman guru tentang pentingnya pendidikan lingkungan yang masih rendah (Hunter \& Jordan, 2019), para guru masih memahami bahwa keberhasilan pembelajaran sebatas dan dinilai dari aspek kognitif semata, sedangkan aspek piskomotor dan afektif sebagai pembentukan karakter siswa masih terabaikan (Purwanti, 2017).

Kemudian, kurangnya menjaga kebersihan diri dengan kenyataan masih bertebarannya sampah di lingkungan sekolah, beralih fungsinya toilet menjadi tempat buang tisu, pembungkus dan lainlain seperti dapat disaksikan di sebagian besar sekolah (Ardianti et al., 2017; Yunansah \& Herlambang, 2017). Juga kesadaran cuci tangan, menggosok gigi dan makan jajanan yang sehat juga masih rendah (Sanjaya et al., 2019). Lebih memprihatinkan lagi hal ini masih banyak terjadi di lingkungan pendidikan yang berbasis Islam terutama madrasah dan pesantren (Hafida \& Wahid, 2018). Kurang terjaganya kebersihan diri mengandung makna bahwa perilaku hidup bersih dan sehat belum diterapkan oleh siswa sepenuhnya. Pada dasarnya Perilaku Hidup Bersih dan Sehat ini bisa diartikan dalam peribahasa Islam "kebersihan adalah sebagian dari iman" atau "Kesucian adalah sebagian dari iman.” (HR. Muslim, Bab Fadhl Al Wudhu, No. 223. Ahmad No. 21834). Dengan menjaga kesehatan dan kebersihan saja, seorang sudah bisa mendapatkan separuh dari iman dalam hal ini keyakinan terhadap Tuhan Yang Maha Esa (Machfutra et al., 2018)

Upaya yang paling tepat untuk menanggulangi tersebut adalah melalui pendidikan (Abdullah et al., 2019), karena pendidikan merupakan daya upaya untuk menumbuhkan budi pekerti, kekuatan batin, karakter, pikiran dan tubuh. Utamanya melalui Pendidikan Agama Islam (Efendi et al., 2017; Idris, 2017). Karena pendidikan Islam mampu membentuk kesalehan pribadi dan kesalehan sosial, salah satu kasalehan tersebut adalan kesalehan ekologis yang berimplikasi pada perilaku hidup bersih dan sehat.

Nilai-nilai yang perlu ditanamkan adalah sikap mencintai kebersihan dan keindahan, dan membiasakan hidup sehat. Nilai ini merupakan pengejawantahan dari nilai-nilai pokok ajaran Islam yaitu, aqidah, akhlak dan ibadah (Muntaha, 2019). Nilai-nilai ini dapat diperoleh melalui Otak dan fungsi akal, serta melalui hati dan fungsi rasa. Kemudian dibentuk dengan cara meningkatkan kesadaran siswa tentang pentingnya peduli lingkungan dan mempunyai inisiatif untuk mencegah kerusakan lingkungan (Purwanti, 2017). Juga melalui pembiasaan cuci tangan, menggosok gigi dengan baik dan benar dan jajan makanan sehat (Sanjaya et al., 2019).

Nilai-nilai tersebut dalam pelaksanaanya diwadahi melaui prinsip-prinsip budaya ekologis 
(Fua \& Wekke, 2017; Muntaha, 2019; Muntaha et al., 2020; Sumantri, 2015) yaitu (1) Muhasabah, bahwa lingkungan dan segala isinya mempunyai status moral dan (2) Muroqobah, setiap orang dituntut dan terpanggil untuk memiliki kedekatan pada alam sebagai perwujudan kedekatan pada Allah, kedekatan pada alam semesta ini sebagai milik bersama dengan rasa memiliki yang tinggi seakan merupakan milik pribadinya. (3) $M u^{\prime}$ ahadah, manusia adalah bagian integral dari alam semesta yang memiliki kedudukan sederajat dan setara dengan alam dan makhluk hidup lainnya. (4) Mu'aqobah, penekanan pada nilai, kualitas, cara hidup yang baik. Bukan pada perolehan sebanyakbanyaknya kekayaan, sarana dan standar material. Yang lebih penting adalah mutu kehidupnan yang lebih mulia dihadapan Allah. (5) Mujahadah, bahwa perilaku manusia satu terhadap yang lainnya dalam sistem sosial harus diatur agar berdampak posistif pada kelestarian lingkungan hidup.

Nilai-nilai tersebut terkejawantahkan menjadi kompetensi yang harus dimiliki oleh siswa, yaitu kompetensi ekologis (Muhaimin, 2015). Kompetensi ini merupakan kemampuan yang berkaitan dengan aspek-aspek ekologi dalam konteks pendidikan yang harus dikuasai oleh siswa dalam pembelajaran, dalam hal ini kepekaan dan kepeduliaan siswa untuk memecahkan masalah lingkungan hidup dalam kehidupan sehari-hari sampai pada tahapan terbentuknya cara pandang dan etika ideal terhadap lingkungan hidup.

Kompetensi ekologis ini memiliki empat elemen pokok yang harus ada yaitu: pengetahuan tentang isu-isu lingkungan, pengetahuan tentang strategi tindakan yang khusus untuk diterapkan pada isu-isu lingkungan, kemampuan untuk bertindak terhadap isu-isu lingkungan dan memiliki kualitas dalam menyikapi serta sikap personalitas yang baik (Muhaimin, 2015).

Menurut Aziz et al (Aziz, 2018) bahwa lingkungan fisik sekolah sangat mempengaruhi pembentukan keterampilan dan partisipasi ekologis siswa. Sejalan dengan temuan Muhaimin (Muhaimin, 2015) bahwa kompetensi siswa terutama dalam hal partisipasi ekologis bukan dipengaruhi oleh kurikulum dan jurusan, tetapi lebih disebabkan oleh faktor lingkungan fisik sekolah.

Selain itu secara psikologis tumbuhan yang rindang di lingkungan madrasah sangat membantu menurunkan tingkat stres. Bahkan menurut psikolog Clayton dan Myers (2014) kondisi lingkungan seperti ini dapat membantu fungsi kognitif lebih efektif, emosi lebih positif, dapat membantu suasana hati lebih damai, sehingga dapat memberi dampak terhadap performa tugas menjadi lebih baik.

Madrasah yang mempunyai kualitas akademik yang bagus identik dengan sekolah yang mempunyai budaya lingkungan yang baik pula (Rahmat et al., 2016). Budaya lingkungan dapat membentuk sekolah yang tidak hanya sehat tetapi juga pintar dalam konteks membuat siswa menjadi betah belajar memacu motivasi belajar sekaligus meningkatkan pengetahuan dengan memanfaatkan berbagai hal dalam sarana dan prasarana akademik dari sekolah.

Berdasarkan penjelasan di atas, maka dapat dipahami bahwa budaya ekologis merupakan suatu pendekatan yang berorientasi pada upaya pengembangan multidomain siswa secara bermakna. Artinya bahwa pembelajaran tidaklah dikembangkan berdasarkan pada orientasi pencapaian domain kognitif semata, melainkan harus mencakup multidomain yang meliputi kognitif, afektif dan psikomotorik.

Berdasarkan pada prinsip pengembangannya, budaya ekologis menekankan pada pengembangan 
materi yang tidak hanya terbatas pada sesuatu yang bersifat tekstual, melainkan perlu dikembangkan melalui pendekatan kontekstual. Artinya bahwa, pembelajaran secara esensial harus dikembangkan dengan menggunakan sumber dan media yang berada dalam konteks kehidupan peserta didik, agar peserta didik mampu mengosntruksi pengetahuan secara bermakna.

\section{Madrasah Tingkat Tsanawiyah Negeri 1} Malang merupakan salah satu Madrasah pilihan, sejak berdirinya telah berkomitmen mengembangkan budaya ekologis, yang tercermin dalam beberapa yaitu (1) lestarinya lingkungan madrasah. Lingkungan Madrasah selalu bersih, sejuk, sehat dan asri. (2) karakter siswa yang peduli lingkungan, bertanggung jawab, dan empati terhadap semua bentuk kehidupan. (3) bermutunya kualitas akademik siswa, dengan berbagai prestasi yang diperoleh (4) citra madrasah yang positif dengan mendapatkan penghargaan dari semua jenis penilaian tentang sekolah bersih dan sehat.

Pada tahun 2007 MTsN 1 Malang mendapat penghargaan dari Gubernur Jawa Timur yaitu Juara 1 Lomba Lingkungan Sekolah Sehat (LLSS) tingkat Provinsi Jawa Timur. Puncaknya pada tahun, 2008 memperoleh dua penghargaan Nasional tentang Sekolah Sehat dari Menteri Pendidikan nasional sebagai Juara 1 Lomba Sekolah Sehat tingkat nasional, dan Juara 1 Lomba Sekolah Sehat tingkat nasional yang diselenggarakan oleh Menteri Kesehatan untuk SMP/MTs. Kemudian pada tahun 2014 mendapat predikat Akreditasi "A" dari Badan Akreditasi Propinsi. Dalam bentuk integritas Madrasah ini telah memperoleh anugerah sekolah berintegritas dari Kementerian Pendidikan Dan Kebudayaan tahun 2015.

Oleh karenanya penelitian ini hendak menggali budaya ekologis yang ada di MTsN 1
Malang yang dapat membentuk perilaku hidup bersih dan sehat melalui dua fokus permasalahan. Pertama, apa nilai-nilai Islam yang mendasari pembentukan budaya ekologis?. Kedua, bagaimana pola pembentukan budaya ekologis?. Melalui penelitian ini juga diharapkan perilaku hidup bersih dan sehat siswa madrasah dapat dikembangkan.

\section{METODE}

Paradigma penelitian ini adalah konstruktivisme sosial yang sering didefiniskan sebagai paradigma interpretif (Creswell, 2018; Sugiyono, 2016). Paradigma ini bertolak dari proses berfikir manusia sebagai individu yang memiliki kebebasan dalam bertindak namun tetap bertanggungjawab. Paradigma ini ini memberikan asumsi bahwa realitas sosial dibangun oleh individu-individu secara sadar dan aktif, sehingga setiap individu mampu memberikan makna terhadap setiap perbuatan yang dilakukan (Creswell, 2018). Fungsi ilmu pengetahuan tidak digunakan untuk menjelaskan dan memprediksi melainkan untuk memahami.

Sedangkan metode yang digunakan adalah kualitatif dengan jenis studi kasus. Di MTsN Malang 1 ini sebagaimana dalil yang disampaikan oleh Yin (2015) kasus yang menjadi fokus penelitian adalah keberhasilan MTsN Malang dalam merealisasikan nilai-nilai Islam dalam membentuk budaya ekologis madrasah yang bersih dan sehat, sehingga budaya ekologis tersebut mampu membangun kesadaran siswanya dalam berperilaku hidup bersih dan sehat.

Subyek penelitian adalah adalah Kepala Sekolah dan Wakil Kepala Sekolah, Komite Sekolah, Guru Bimbingan dan Konseling, TIM Guru Mata Pelajaran Agama Islam, Duta Lingkungan, Pengelola Kantin dan Pengurus UKS. Pengumpulan data penelitian ini secara berurutan adalah wawancara mendalam dengan subjek penelitian. Untuk memperoleh hasil 
wawancara yang utuh peneliti akan mendokumentasikan hasil wawancara dalam bentuk rekaman dan catatan. Kemudian kelengkapan data akan diperdalam dengan teknik observasi partisipan secara langsung dan tidak langsung serta penelusuran dokumen.

Prosedur analisis data yang digunakan mengadopsi prosedur yang ditulis oleh Miles and Huberman, yaitu data reduction, data display, dan conclusion drawing/verification. Bagian terakhir adalah melakukan pemeriksaan atau pengecekan keabsahan data dan informasi yang diperoleh di lapangan. Creswell (2018) menyarankan delapan strategi yang sering dilakukan untuk memeriksa keabsahan data yaitu (1) keterlibatan jangka panjang, (2) triangulasi, (3) ulasan dan tanya jawab dengan teman sejawat, (4) analisis kasus negatif, (5) mengklarifikasi bias peneliti, (6) pemeriksaan anggota, (7) deskripsi yang tebal dan kaya, (8) audit eksternal. Mempertimbangkan rekomendasi dari creswell, langkah yang ditempuh untuk menguji kepercayaan terhadap data hasil penelitian yang peneliti lakukan ada dua yaitu perpanjangan pengamatan dan trianguasi.

\section{HASIL DAN PEMBAHASAN}

a. Hasil Penelitian

Penelitian ini berhasil menjelaskan pembentukan budaya ekologis siswa Madrasah Tingkat Tsanawiyah Negeri 1 Kota Malang, dijabarkan berdasarkan pokok permasalahan.

\section{Nilai-nilai Islam yang menjadi spirit pembentukan budaya ekologis siswa.}

Untuk memahami pembentukan budaya ekologis di MTsN 1 Malang perlu peneliti desrkipsikan terlebih dahulu tentang nilai-nilai yang dijadikan dasar dalam pembentukan budaya ekologis. Nilai-nilai tersebut adalah tauhid, uswah hasanah dan kepedulian.
1.1. Tauhid.

Nilai yang menjadi dasar utama dalam pembentukan budaya ekologis adalah tauhid. Secara sederhana, tauhid ditanamkan kepada siswa dengan prinsip bahwa lingkungan disekitar adalah makhluk Allah juga, makhluk lain selain manusia juga butuh kehidupan sesuai dengan fungsi dan tugasnya, keberadaan makhluk tersebut adalah untuk kemaslahatan manusia, makhluk tersebut merasa senang dan berterimakasih kepada manusia, jika manusia memperlakukan makhluk tersebut secara adil, sampah yang berserakan tidak pada tempatnya akan menjadi saksi dihadap Allah. Sebaliknya sampah yang dipungut kemudian diletakkan pada tempatnya ia akan berterimaksih dan mendoakan orang tersebut supaya mendapat rahmat Allah.

Nilai tauhid ini dibentuk melalui pembiasaan salat, terutama salat berjamaah, salat dijadikan sebagai media utama dalam proses pembelajaran, begitupula dalam penanaman nilai-nilai kecintaan kepada lingkungan. Sebagai lembaga madrasah yang bersendikan Islam wajar jika salat sebagai pembiasaan. Namun berdasarkan hasil pengamatan dan wawancara setidaknya tiga hal yang membedakan, pertama sebelum proses pembelajaran dan kegiatan yang lainnya, seluruh civitas madrasah menjalankan salat duha baru kemudian siswa mendapatkan pembelajaran, dan sebelum pulang seluruh civitas melaksanakan salat, salat Jum'at untuk hari jum'at, salat dhuhur untuk hari sabtu dan salat asar untuk hari senin s.d kamis. Kedua dalam menentukan pilihan kepada siswa untuk mengemban amanah tertentu, salat dijadikan sebagai persyaratan utama selain persyaratan yang sesuai dengan amat yang diberikan. Ketiga istiqomah, dalam hal ini peneliti menemukan bahwa salat yang dilaksanakan bukan menjadi kewajiban yang harus ditunaikan, sehingga kalau tidak ikut salat mendapat dosa dari 
Allah, dan atau mendapat sanksi dari guru, lebih dari itu seluruh civitas termasuk siswa ketika suara azan berkumandang siswa dan guru segera menuju masjid dengan senangnya, jumlah yang melaksanakan salat juga konsisten, pengurangan jumlah terjadi hanya pada siswi atau guru perempuan karena sedang haid, bahkan ada beberapa siswa yang sudah siap salat sebelum azan berkumandang. Berikut adalah wawancara dengan Guru Bimbingan dan Konseling;

"Nilai-nilai religius di MTsN Malang 1 dibangun melalui pembiasaan Salat Dhuha setiap pagi sebelum pelaksanaan pembelajaran, membaca Al-Quran setelahnya dan sebelum pulang sekolah siswa-siswi dibiasakan sholat Dhuhur untuk hari Jumat dan sabtu, Sholat asar untuk hari senin-kamis. Pembiasaan mengawali pembelajaran dengan salat dan mengakhirinya dengan salat diharapkan mampu menanamkan nilai religius kedalam diri siswa-siswi, sehingga sikap dan perilaku mereka tercermin ketika mereka berhubungan dengan sesama dan lingkungannya' (Wawancara).

Menarik menurut peneliti, bahwa untuk memilih ketua organisasi siswa salat dijadikan sebagai persyaratan pertama dan utama, kemudian baru persyaratan yang lainnya. Menurut guru Bimbingan Konseling, selama ini siswa yang shalatnya relatif baik kecenderungannya dalam pembelajaran dan kegiatan lainnya juga lebih baik, walaupun tidak mutlak. Siswa yang peneliti konfirmasi juga menyampaikan hal yang sama, ketika dirinya mencalonkan diri sebagai ketua Duta Lingkungan maka dalam tahap wawancara guru BK akan menanyakan lebih jauh tentang shalatnya selama ini, dipadukan dengan pengamatan dan penilaian dari guru. Hasilnya manakala baik maka pencalonan akan dilanjutkan, manaka belum baik, guru BK akan memberikan bimbingan lebih lanjut.

Selain melalui salat, nilai tauhid ini juga ditanamkan melalui mimbar duha, sebelum proses pembelajaran dimulai, seluruh civitas madrasah menjalankan salat dhuha baru kemudian siswa mendapatkan pembelajaran, pada momentum inilah guru, guru BK dan tim Duta Lingkungan memberikan pemahaman tentang kompetensi ekologis, biasanya 5-10 menit waktu yang dibutuhkan setelah sholat selesai. Sebelum pulang seluruh civitas melaksanakan salat asar untuk hari senin s.d kamis, salat Jum'at untuk hari jum'at dan salat dhuhur untuk hari sabtu.

\subsection{Pembiasaan.}

Bentuk kepedulian yang ditanamkan kepada siswa adalah melibatkan siswa dalam menjaga kebersihan kelas, kebersihan lingkungan, kebersihan kamar mandi, penghematan listrik dan air. Kebersihan kelas ditanamkan dengan melibatkan siswa dalam mengatur dan mengelola kelas melalui piket kelas. Setiap pagi sebelum pembelajaran dilaksanakan siswa yang mendapat giliran piket memastikan karpet kelas bersih tanpa sampah, meja dan kursi kelas bersih dan papan tulis bersih dan siap pakai. Tak jarang peneliti jumpai siswa membersihkan karpet kelas dengan cara di vacum, bahkan dan ada juga kelas yang memiliki vacum sendiri.

Kebersihan lingkungan ditanamkan melalui peran serta siswa dalam gerakan meletakkan sampah pada tempatnya. Menjaga kebersihan kamar mandi ditanamkan melalui sikap menyiram air secukupnya dan tidak meninggalkan kamar mandi dalam kondisi berbau. Sedangkan kepedulian dalam hemat air dan listrik ditanamkan melalui sikap hemat air saat cucu tangan, buang air dan mematikan kran yang menyala tidak pada waktunya, serta mematikan lampu yang menyala tidak pada waktunya. Hasil wawancara bahwa dalam menanamkan nilai kepedulian terhadap kebersihan, siswa diupayakan dilibatkan langsung dalam setiap pelaksanaan mulai dari perencanaan, pelaksanaan hingga pendanaan. 
Penanaman nilai kepedulian yang lainnya dilakukan melalui pembiasaan membersihkan dan merapikan tempat makan siang. Setiap hari siswa MTsN 1 Malang makan siang di kelas masing-masing, karena jam sekolah sampai menjalang asar. Siswa dibiasakan membersihkan dan merapikan tempat makan dan minum yang telah dipakai. Berdasarkan pengamatan kepedulian siswa dalam hal ini masih cukup beragam, siswa kelas VII kesadaran masih agak rendah, tempat makanan dan sisa makanan yang peneliti perhatikan masih cukup banyak berada di atas bangku siswa, sementara kelas VIII sudah mulai meningkat kesadarannya, sampah dan sisa makanan telah dikumpulkan di depan kelas namun masih ada sebagian yang sengaja tidak dimasukkan ke tempat sampah, kondisi ini berbeda dengan siswa kelas IX, kelas sudah kembali bersih dan rapi seperti sebelum. Seabagimana hasil wawancara dengan wakil kepala sekolah bidang kesiswaan berikut ini:

"saat-saat tertentu siswa kami ajak ke
sudut-sudut madrasah, mereka kami ajak
untuk membersihkan sampah dan yang
lainnya yang di buang oleh teman-teman
mereka, terkadang kita ajak
membersihkan konopi yang ada
sampahnya yang bukan mereka yang
membuangnya, pada kesempatan ini
biasanya kita sampaikan hal-hal yang
berhubungan dengan kejadian tersebut,
kita jelaskan kalau sampah di kanopi ini
kita biarkan, kemudian menyumbat atap
apa yang akan terjadi, hal ini kita lakukan
bersama guru dengan demikian harapan
kami anak-anak semakin terbuka
wawasan dan kepeduliannya"
(wawancara).

\subsection{Uswatun Hasanah}

Uswatun Hasanah terdiri dari kata uswatun artinya, ikutan, panutan dan hasanah artinya yang baik. Jadi uswatun hasanah adalah contoh suri teladan yang baik (Taklimudin \& Saputra, 2018). Taklimudin dan Saputra mendalilkan bahwa dalam berlangsungnya proses pendidikan uswatun hasanah dapat diterapkan dalam dua bentuk secara bersamaam yaitu secara langsung dan secara tidak langsung. Secara langsung maksudnya adalah guru benar-benar mengaktualisasikan dirinya sebagai contoh teladan yang baik bagi siswa. Sedangkan tidak langsung bermakna guru memberikan teladan kepada siswanya dengan cara menceritakan kisah-kisah teladan yang baik dalam bentuk riwayat nabi, kisah orang-orang besar, pahlawan dengan tujuan agar siswa menjadikan tokoh-tokoh tersebut sebagai suri tauladan dalam kehidupan mereka (Taklimudin \& Saputra, 2018).

Uswah hasanah untuk menciptakan lingkungan madrasah yang bersih dan sehat dilakukan oleh seluruh civitas madrasah, mulai dari kepala madrasah sampai dengan siswa. Uswatun hasanah guru yang peneliti peroleh dari hasil pengamatan adalah saat kegiatan sabtu bersih. Guru bahu membahu bersama siswa mencari dan membersihkan lingkungan madrasah. Hal ini memberikan pemahaman kepada siswa bahwa guru senantiasa mencontohkan apa yang diucapkan. Karenanya siswa tidak memiliki alasan lain untuk tidak mencontoh gurunya.

Uswah hasanah lainnya dibentuk melalui organisasi Duta Lingkungan. Siswa-siswi yang menjadi anggota di organisasi ini sejak awal memang dididik dan dibina sebagai contoh hidup bagi temanteman sebayanya, hal yang lumrah jika yang mendaji tauladan adala guru, karena hal tersebut sudah menjadi jiwanya, akan menjadi hal yang luar biasa jika siswa bisa menjadi teladan bagi siswa lainnya. Siswa yang mengikuti organisasi duta lingkungan dijadikan role model untuk teman sebayanya diluar organisasi, sehingga pemodelan ini lebih mudah diterima oleh teman sebayanya. Sebagaimana disampaikan oleh Guru BK sekaligus pembina Duta Lingkungan; 
"untuk anak-anak yang menjadi duta lingkungan, diharapkan mereka bisa menjadi teladan bagi teman-temannya terkait dengan pengelolaan lingkungan disini, melebihi kepedulian temantemennya terhadap keberadaan sampah, jadi bukan hanya peduli yang akhirnya memungut sampah yang ada, lebih dari itu mereka juga bertanggung jawab untuk mengingatkan untuk bisa bersama-sama mempengaruhi teman-teman agar faham terhadap keberadaan sampah yang benar itu ada dimana" (wawancara).

\section{Pola Pembentukan Budaya Ekologis Siswa}

Pembentukan budaya ekologis siswa di MTsN 1 Malang dilakukan melalui tahapan-tahapan berikut ini:

\subsection{Kurikulum}

Kurikulum yang digunakan di MTsN Malang 1 adalah kurikulum tahun 2013 (K-13) yang berlaku secara nasional, dalam pelaksanaannya ditambahkan dan disesuaikan dengan Visi Misi Madrasah. Perlu diketahui bahwa guru-guru di MTsN 1 Malang sebagian besar menjadi tim perumus dan pengembang Kurikulum, terutama kurikulum Pendidikan Agama Islam (PAI).

Berdasarkan hasil wawancara dan penelusuran dokumentasi bahwa budaya ekologis yang ditanamkan melalui kurikulum Pedidikan Agama Islam secara implisit dan eksplisit terdapat pada mata pelajaran Fiqh, Akidah Akhlak, Qur'an Hadits, Sejarah Kebudayaan Islam dan Bahasa Arab.

Mata pelajaran Qur'an Hadits sebagai pembentukan budaya ekologis secara ekplisit terdapat pada materi-materi berikut: pertama, memahami hadits tentang kebersihan yaitu Hadist Riwayat Muslim dari Abi Malik al-Ansyari. Kedua, memahami Hadist tentang menghidupkan lahan mati yang diriwayatkan oleh abu Daud dan Ahmad dari Sa'id bin Zaid: barang siapa mengolah tanah yang mati maka tanah tersebut menjadi miliknya. Ketiga, memahami hadits tentang pemeliharaan lingkungan yang diriwayatkan oleh Bukhari dan Muslim dari Anas bin Malik. "Tidaklah seorang mukmin yang menanam pohon atau sebuah tanaman kemudian dimakan burung, atau dimakan oleh manusia atau dimakan oleh binatang ternak lainnya melainkan baginya pahala sedekah" . Keempat, budaya menjaga kelestarian lingkungan yang merupakan implementasi dari QS ar-Rum 41, al-A'raf: 56-58, Shad: 27, alFurqaan: 45-50, al-Baqarah: 204-206.

Mata pelajaran Akidah Akhlak sebagai pembentuk budaya ekologis secara garis besar masih terfokus pada materi meneladani contoh-contoh akhlak terpuji (mahmudah) serta menghindari prilaku tercela (mazmumah) diantaranya; akhlak yang baik terhadap binatang dan tumbuhan dalam kehidupan sehari-hari, membiasakan prilaku hidup bersih dan sehat, meyakini dan terbiasa bertauhid dalam kehidupan sehari-hari yaitu penerapan nilainilai tasawuf dalam kehidupan modern dan menghindari perilaku isyrof, tabzir dan bakhil.

Mata Pelajaran Fiqih terdapat pada materi "thaharah", mengkonsumsi minuman dan makan halal, serta materi Haji dan umrah. Sedangkan mata pelajaran sejarah kebudayaan Islam dijadikan sebagai pembentuk budaya ekologis penekanannya melalui uswatun hasanah yang dikisahkan dan dialami oleh generasi muslim terdahulu, diantaranya melalui materi kisah nabi-nabi Allah, tarikh Rasulullah SAW dan al-Khulafa' al-Rasyidun serta kaum Muhajirin dan Anshar. Tarikh Rasulullah SAW, menceritakan sejarah pertumbuhan ilmu pengetahuan Islam sampai masa Abbasiyah, sejarah perkembangan Islam di nusantara serta sejarah tradisi Islam nusantara.

\subsection{Lingkungan Madrasah}

Dalam upaya mendukung terhadap penanaman nilai-nilai budaya ekologis, landasan dasar yang digunakan adalah visi dan misi Madrasah. Visi MTsN 
1 Malang adalah menjadi madrasah berkualitas unggul dalam IMTAQ dan IPTEK yang berstandar internasional. Visi dan misi tersebut senantiasa menjiwai dan menjadi inspirasi dalam pengembangan dan pengelolaan madrasah, termasuk didalamnya adalah pengelolaan lingkungan madrasah.

Bentuk Pengelolaan lingkungan yang mendukung penanaman nilai-nilai budaya ekologis adalah: mimpi, kerja keras dan sangat mementingkan proses. Ketiga hal ini adalah ruh yang menggerakkan pengelolaan lingkungan madrasah. Mimpi yang menjadi penggerak adalah impian menghilangkan stigma negatif madrasah yang selalu identik dengan kumuh dan jorok, dengan mewujudkan madrasah hijau.

Keberadaan taman yang diupayakan membantu kenyamanan siswa, dilengkapi dengan gazebo dan berada pada sudut yang sesuai. Beberapa titik dilengkapi dengan kolam ikan. Hal ini menjadikan madrasah rindang dan asri serta dapat dijadikan laboratorium alami dalam mendukung penanaman budaya ekologis.

Keberadaan tempat cuci tangan yang mudah dijangkau oleh siswa, sehingga memudahkan guru dalam menanamkan nilai-nilai kebersihan dan kesehatan. Begitu pula keberadaan tempat sampah yang merata disetiap tempat, disesuaikan dengan volume sampah yang dihasilkan oleh siswa. Tempat sampah dibersihkan setiap sabtu memberikan kemudahan dalam menanamkan kesadaran menempatkan sampah pada tempatnya dan kesadaran dalam menjada kebersihan.

Keberadaan kebun Sekolah, biasanya siswa mengisi dengan kegiatan menanam sawi dan kangkung, apabila panen tiba guru siap membelinya. Hal ini dijadikan sebagai sarana siswa untuk lebih mendekatkan diri kepada alam, terutama kasih sayang terhadap tumbuhan. siswa menjadi tau tanaman dan fungsinya, mengenal berbagai jenis tanaman dan segala instrumen pendukungnya hal ini dapat membantu menumbuhkan nilai kepedulian dan kecintaan terhadap lingkungan.

Pada kesimpulannya sebagaimana hasil wawancara dengan kepala sekolah bahwa pengelolaan lingkungan madrasah dikelola sepenuhnya untuk mendukung tercapainya visi dan misi sekolah, salah satunya misi keenam yaitu meningkatkan budaya hidup sehat untuk mewujudkan generasi yang kompetitif.

\subsection{Duta Lingkungan}

Organisasi duta lingkungan dibentuk pada tahun 2013, organisasi ini merupakan bagian dari Organisasi Siwa Intra Sekolah yaitu seksi bidang III bidang pemeliharaan lingkungan dan kebersihan. Organisasi ini agak unik menurut peneliti, karena dalam hal pemilihan anggota persyaratannya adalah yang sholatnya baik. Sedangkan untuk ketua kriteria utama sholatnya lebih baik, dan mempunyai bibit-bibit kepemimpinan. Periode kepemimpinan 1 tahun menyesuaikan dengan tahun ajaran. Penetapan sebagai ketua ditentukan oleh pembina Duta Lingkungan dalam hal ini juga sebagai Guru BK.

Fungsi utama organisasi ini adalah sebagai agen of change yang menjadi penggerak kebersihan dan kesehatan lingkungan. Berikut adalah tugas dan program kerja organisasi Duta Lingkungan:

a. Gerakan sabtu bersih.

Gerakan santu bersih ini dimulai sebelum proses pembelajaran dimulai, biasanya jam 06.30. seluruh siswa dimotori oleh Duta Lingkungan membersihkan seluruh area sekolah. Gerakan Sabtu Bersih ini bertujuan untuk menumbuhkan rasa peduli lingkungan pada siswa. Sehingga para siswa tidak hanya mengandalkan petugas dalam menjaga kebersihan dan kerapian lingkungan. Harapannya akan tumbuh kepedulian siswa untuk selalu 
membuang sampah pada tempatnya serta menjaga kerapian lingkungan madrasah.

Kebersihan lingkungan madrasah bisa tercipta bukan karena banyaknya petugas kebersihan. Namun, kebersihan lingkungan madrasah akan tercipta dengan kepedulian seluruh warga madrasah untuk selalu menjaga kebersihan lingkungannya.

Berdasarkan Wawancara dengan pembina Duta Lingkungan bahwa tujuan dari gerakan Sabtu Bersih adalah untuk membentuk karakter siswa agar mempunyai kepedulian pada lingkungan di sekitar mereka. Inisiator dari Gerakan Sabtu Bersih ini adalah Duta Lingkungan yang akhirnya mendapat dukungan baik dari pihak madrasah dan organisasi-organisasi lainnya. Diharapakan adanya kegiatan ini bisa menumbuhkan kebiasaan pada siswa untuk senantiasa menjaga kebersihan diri sendiri dan lingkungannya. Hal ini juga bisa menjadi karakter positif dalam diri siswa dimanapun dia berada.

Sabtu bersih itu bukan untuk area luar saja, tetapi juga area di dalam kelas. Yaitu di kolong meja atau disudut-sudut kelas harus bersih. Para siswa harus punya kepedulian untuk selalu menjaga kebersihan di manapun mereka berada. Pak Muji juga berharap para siswa mempunyai rasa memiliki madrasah ini. Sehingga para siswa tidak hanya menikmati sarana dan prasarana madrasah, tapi juga turut menjaga dan merawatnya.

Salah satu siswa ketika diwawancarai peneliti menyampaikan bahwa kegiatan Sabtu Bersih ini mampu memberi efek positif pada siswa untuk peduli terhadap lingkungan madrasah. Walaupun namanya Sabtu Bersih kegiatannya tidak hanya membersihkan madrasah. Namun, juga ada senam atau renungan yang dipimpin Guru BK yang juga Pembina Duta Lingkungan. Sabtu bersih juga bisa mempererat hubungan antar organisasi. b. Menyelenggarana even sesuai dengan momentum seperti hari bumi, hari AIDS dll.

c. Melatih membudidayakan tanaman sehat dan produktif. Siswa diajarkan membudidayakan sawi dan kangkung. Apabila hasilnya panen akan dijual ke bapak/ibu guru. Begitu pula siswa dilatih membudidayakan tanaman sehat yaitu tanaman toga, tanaman toga berasal dari siswa yang baru masuk, siswa baru harus membawa satu tanaman toga yang di tanam di kebun sekolah. Siswa sebagai pemilik diberi tanggung jawab untuk merawat tanamannya hingga berhasil.

d. Mendata anak-anak yang membuang sampah sembarangan dan makan sambil berdiri atau berjalan, untuk disampaikan ke guru BK. siswa yang ketahuan akan diberi sanksi membersihkan kamar mandi. Atau siswa yang kedapatan saat makan sambil berjalan akan difoto, kemudian disampaikan kepada Guru BK untuk selanjutnya dipajang di mading Madrasah.

Duta Lingkungan ini sangat penting bagi keberlangsungan proses penanaman nilai-nilai kebersihan dan kesehatan lingkungan, terutama nilainilai Islam yang menjadi visi madrasah. Perannya lebih tepat sasaran karena obyek penanaman sesama siswa, sehingga proses mengingatkan dan tutor sebaya tidak mengalami kendala. Nilai yang selalu di sampaikan setiap saat adalah "kita adalah duta lingkungan, jadi kita harus punya kesadaran diri, kalau ada sampah ya harus langsung diambil dan kita buang ditempatnya, kita sendiri juga harus membuang sampah pada tempatnya, dan kalau ada temen2 yang buang sampah dingetin" (wawancara).

\section{b. Pembahasan}

Temuan di lapangan menunjukkan bahwa budaya ekologis MTsN 1 Malang sangat berperan dalam membentuk Perilaku Hidup Bersih dan Sehat 
siswanya. Menurut Muhaimin sekolah yang mempunyai budaya ekologis yang baik, tingkat kesadaran ekologis siswanya juga akan baik. Terutama pada aspek keterampilan dan pasrtisipasi jika dibandingkan dengan sekolah yang kurang mempunyai budaya ekologis. Budaya ekologis yang dikembangkan MTsN 1 Malang berasaskan pada nilai tauhid. Nilai yang menjadi dasar utama dalam pembentukan budaya ekologis adalah tauhid.

Secara sederhana, tauhid ditanamkan kepada siswa dengan prinsip bahwa lingkungan disekitar adalah makhluk Allah juga, makhluk lain selain manusia juga butuh kehidupan sesuai dengan fungsi dan tugasnya, keberadaan makhluk tersebut adalah untuk kemaslahatan manusia, makhluk tersebut merasa senang dan berterimakasih kepada manusia, jika manusia memperlakukan makhluk tersebut secara adil. Nilai ini sejalan dengan prinsip mu'ahadah (Sumantri, 2015) artinya setiap tindakan atau prilaku manusia yang berhubungan dengan orang lain atau makhluk lain atau lebih khusus lingkungan hidupnya selalu dilandasi keyakinan bahwa keesaan dan kekuasaan Allah SWT adalah mutlak.

Nilai ini juga merupakan penjabaran nilai aqidah, nilai akhlak dan nilai ibadah. Nilai ini memuat aturan-aturan Allah yang mengatur tentang hubungan manusia dengan Allah, hubungan manusia dengan manusia, dan hubungan manusia dengan alam. Manusia akan mengalami ketidak-nyamanan, ketidakharmonisan, ketidaktentraman, atau pun mengalami permasalahan dalam hidupnya, jika dalam menjalin hubungan-hubungan tersebut terjadi ketimpangan atau tidak mengikuti aturan yang telah ditetapkan oleh Allah.

Tauhid ini dibangun melalui pembiasaan Salat Dhuha setiap pagi sebelum palaksanaan pembelajaran, membaca Al-Quran setelahnya dan sebelum pulang sekolah siswa-siswi dibiasakan shalat asar untuk hari
Senin-Kamis, shalat jumat pada hari jumat dan shalat dhuhur untuk hari sabtu. Pembiasaan mengawali pembelajaran dengan Salat dan mengakhirinya dengan salat diharapkan mampu menanamkan nilai tauhid kedalam diri siswa-siswi, sehingga sikap dan perilaku mereka tercermin ketika mereka berhubungan dengan sesama dan lingkungannya.

Langkah selanjutnya, dalam pembentukan budaya ekologis siswa dilakukan melalui kurikulum Pendidikan Agama Islam integratif (Nuha, 2017). Dalam praktiknya, materi tentang lingkungan yang terdapat dalam Pendidikan Agama Islam diterapkan secara langsung melalui tadabbur alam, yakni materi PAI disampaikan kepada siswa melalui kegiatan sabtu bersih. Pada kesempatan ini Guru Bimbingan Konseling menjelaskan hadist tentang kebersihan, kemudian diperkuat kembali melalui mimbar duha. Dimana Guru PAI akan menjelaskan kisah-kisah teladan yang berkenaan dengan kebersihan.

Secara teori tadabbur alam ini menurut Ardianti et al (2017) bisa disandingkan dengan model pembelajaran Experiential Jelajah Alam Sekitar (EJAS). Model pembelajaran EJAS merupakan model pembelajaran yang memberikan pengalaman secara langsung kepada siswa serta dapat mengembangkan kemampuan dan potensi siswa melalui tahapan eksplorasi, interaksi, komunikasi dan refleksi. Tujuan model pembelajaran EJAS adalah untuk menggali, membangun, melatih, dan membiasakan kemampuan personal, sosial, berpikir rasional, metakognisi, dan kognisi siswa dalam proses pembelajaran Pendidikan Agama Islam yang berorientasi pada pencapaian kompetensi ekologis.

Materi tentang lingkungan tetap diberikan melalui pembelajaran dalam kelas namun dengan porsi minimal. Pembelajaran dalam kelas ini tetap penting dilakukan untuk menumbuhkan literasi ekologis siswa. Menurut Goulgouti, Plakitsi, \& Stylos 
(2019) bahwa perilaku lingkungan yang bertanggung jawab berkorelasi dengan pengetahuan. Materi tersebut antara lain hadits tentang kebersihan, hadist tentang menghidupkan lahan mati, hadits tentang pemeliharaan lingkungan, ayat Al-Quran tentang budaya menjaga kelestarian lingkungan yang terdapat dalam mata pelajaran Quran Hadist, akhlak baik terhadap binatang dan tumbuhan dalam kehidupan sehari-hari, meyakini dan terbiasa bertauhid dalam kehidupan sehari-hari, materi "thaharah", mengkonsumsi minuman dan makan halal, serta materi Haji dan Umrah (Jatmiko, 2016; Muntaha, 2019). Pembelajaran model integratif ini dapat memberikan pengalaman langsung dan dapat mengembangkan potensi siswa serta efektif.

Membentuk sikap, perilaku dan partisipasi berbudaya ekologis memerlukan pembiasaan (Hafida \& Wahid, 2018). Pembiasaan ditanamkan melalui pelibatan siswa dalam menjaga kebersihan kelas, kebersihan lingkungan, kebersihan kamar mandi, penghematan listrik dan air. Selain itu pembiasaan membersihkan dan merapikan tempat makan siang. Keterlibatan siswa dalam kegiatan tersebut dimulai dari perencanaan, pelaksanaan hingga pendanaan. Model pelibatan langsung ini merupakan model pendidikan yang lebih berhasil dalam membentuk karakter (Lickona, 2015). Pembiasaan ini diharapkan bisa menjadi budaya ekologis, sehingga dapat membangun mentalitas ekologis siswa ke arah yang lebih baik.

Membentuk kebiasaan ekologis siswa perlu adanya uswatun hasanah terutama dari orang dewasa di sekitar siswa, uswatun hasanah ini dilakukan oleh warga madrasah terutama oleh kepala sekolah dan guru. Uswatun hasanah ini dapat dimulai dari hal-hal yang sederhana. Siswa juga menjadi teladan bagi siswa yang lainnya, terutama siswa yang menjadi anggota duta lingkungan. Pemodelan sebaya ini menjadi efektif dalam membentuk budaya ekologis (Azmi et al., 2018).

Gerakan bersama yang dilakukan oleh MTsN 1 Malang melalui organisasi siswa Duta Lingkungan. Organisasi ini dibentuk sebagai agen yang menjadi penggerak kebersihan dan kesehatan lingkungan bagi siswa. Melalui komando Guru BK seluruh sivitas madrasah akan melaksanakan kegiatan sabtu bersih. Kepala Madrasah juga andil dalam kegiatan ini. Pada momen ini siswa dilibatkan secara langsung dalam mengelola kebersihan dan keindahan madrasah. Gerakan bersama ini dilakukan oleh semua komponen Madrasah dengan bersinergi dalam mencapai tujuan pembentukan budaya ekologis.

Melalui organisasi Duta Lingkungan siswa dilibatkan untuk menyusun program kerja dan anggaran, sehingga dapat membentuk pengetahuan, sikap dan kebiasaan ekologis siswa menjadi efektif. Selain itu duta lingkungan ini sangat efektif mengarahkan motivasi siswa dalam membentuk mentalitas dan kesadaran ekologis siswa. Hal ini diperkuat hasil penelitian Muhaimin bahwa tingkat kesadaran siswa yang mengikuti kegiatan ektrakulikuler lingkungan seperti pramuka lebih baik dibandingkan dengan siswa yang tidak mengikuti ekstrakurikuler (Muhaimin, 2015).

Lingkungan fisik MTsN 1 Malang diupayakan dapat membantu kenyamanan siswa dalam belajar, gazebo sebagai tempat diskusi dan bercengkrama antar siswa. Taman yang dilengkapi dengan kolam ikan. Pepohonan yang rindang dan asri, tempat cuci tangan yang mudah dijangkau oleh siswa, Tempat sampah yang merata disetiap tempat, dan kebun Madrasah, biasanya siswa mengisi dengan kegiatan menanam sawi dan kangkung, apabila panen guru siap membelinya. Hal ini dijadikan sebagai sarana siswa untuk lebih mendekatkan diri kepada alam, terutama kasih sayang terhadap tumbuhan sehingga karakter 
siswa dapat tumbuh dan berkembang (Lickona, 2015). Siswa menjadi tau tanaman dan fungsinya, mengenal berbagai jenis tanaman dan segala instrumen pendukungnya hal ini dapat membantu menumbuhkan nilai kepedulian dan kecintaan terhadap lingkungan. Sesuai misi keenam madrasah yaitu meningkatkan budaya hidup sehat untuk mewujudkan generasi yang kompetitif.

Menurut Aziz et al (2018) lingkungan apalagi lingkungan sekolah sangat mempengaruhi pembentukan keterampilan dan partisipasi ekologis siswa. Sejalan dengan temuan Muhaimin bahwa kompetensi siswa terutama dalam hal partisipasi ekologis bukan dipengaruhi oleh kurikulum dan jurusan tetapi lebih disebabkan oleh faktor lingkungan sekolah (Muhaimin, 2015). Selain itu secara psikologis tumbuhan yang rindang di lingkungan madrasah sangat membantu menurunkan tingkat stres. Bahkan menurut Clayton dan Myers kondisi lingkungan seperti ini dapat membantu fungsi kognitif lebih efektif, emosi lebih positif, dapat membantu suasana hati lebih damai, sehingga dapat memberi dampak terhadap performa tugas menjadi lebih baik (Clayton \& Myers, 2014). Madrasah yang mempunyai kualitas akademik yang bagus identik dengan sekolah yang mempunyai budaya lingkungan yang baik pula (Rahmat et al., 2016). Budaya lingkungan dapat membentuk sekolah yang tidak hanya sehat tetapi juga pintar dalam konteks membuat siswa menjadi betah belajar memacu motivasi belajar sekaligus meningkatkan pengetahuan dengan memanfaatkan berbagai hal dalam sarana dan prasarana akademik dari sekolah.

Berdasarkan penjelasan di atas, maka dapat dipahami bahwa budaya ekologis merupakan suatu pendekatan yang berorientasi pada upaya pengembangan multidomain siswa secara bermakna. Artinya bahwa pembelajaran tidaklah dikembangkan berdasarkan pada orientasi pencapaian domain kognitif semata, melainkan harus mencakup multidomain yang meliputi kognitif, afektif dan psikomotorik. Berdasarkan pada prinsip pengembangannya, budaya ekologis menekankan pada pengembangan materi yang tidak hanya terbatas pada sesuatu yang bersifat tekstual, melainkan perlu dikembangkan melalui pendekatan kontekstual. Artinya bahwa, pembelajaran secara esensial harus dikembangkan dengan menggunakan sumber dan media yang berada dalam konteks kehidupan peserta didik, agar peserta didik mampu mengosntruksi pengetahuan secara bermakna.

Berdasarkan hal tersebut, pembelajaran harus berbasis pada pendekatan interdisipliner dalam rangka memperkaya pengetahuan dan pemahaman peserta didik secara komprehensif. Selain dari itu, budaya ekologis beroerientasi pada pencapaian pemahaman secara utuh tentang hakikat manusia dan alam yang memiliki relasi esensial, sehingga hal ini berimplikasi pada tumbuhnya kesadaran kritis dan terbangunnya karakter peserta didik.

Pemahaman inilah yang membentuk kesadaran untuk mereposisi interaksi manusia dengan lingkungan hidupnya untuk memperbaiki dan meningkatkan kualitas kehidupan manusia secara keseluruhan serta kemampuan mendayagunakan lingkungan sesuai dengan fungsinya sehingga dalam kesaharian siswa mampu berperilaku hidup bersih dan sehat.

\section{KESIMPULAN}

Budaya ekologis yang dikembangkan di MTsN 1 Malang yaitu (1) penanaman nilai Tauhid melalui pembiasaan salat. (2) penerapan kurikulum Pendidikan Agama Islam Integratif, pembiasaan, (4) uswatun hasanah (5) gerakan 
bersama dalam wadah duta lingkungan (6) lingkungan madrasah yang kondusif. Budaya ekologis telah dilaksanakan dengan komitmen yang tinggi sehingga mampu membentuk perilaku hidup bersih dan sehat siswa menjadi lebih baik.

\section{UCAPAN TERIMA KASIH}

Ucapan terimakasih penulis haturkan kepada segenap Civitas MTsN 1 Malang yang telah menfasilitasi pelaksanaan penelitian ini, tak lupa kepada Pimpinan STIKES Widyagama Husada yang telah memberikan support sehingga penelitian ini dapat dipublikasikan.

\section{DAFTAR RUJUKAN}

Abdullah, N., Wong, K.-T., Mansor, R., Halim, L., \& Mohd Affandi, H. (2019). Development of Environmental Education Model for Primary School Pupils in Malaysia. The Journal of Social Sciences Research, 5(54), 1187-1192. https://doi.org/10.32861/jssr.54.1187.1192

Anam, K. (2016). Pendidikan Perilaku Hidup Bersih dan Sehat dalam Perspektif Islam. Jurnal Sagacious, 3(1), 67-78.

Ardianti, S. D., Wanabuliandari, S., \& Rahardjo, S. (2017). Peningkatan Perilaku Peduli Lingkungan Dan Tanggung Jawab Siswa Melalui Model Ejas Dengan Pendekatan Science Edutainment. Jurnal Ilmiah Pendidikan Dasar, 4(1), 1-7.

Aziz, F. (2018). Linking Islamic Work Ethics and ProEnvironmental Behaviour: A Systematic Review. The Journal of Social Sciences Research, SPI 2, 249-256. https://doi.org/10.32861/jssr.spi2.249.256

Aziz, F., Mahadi, N., \& Mohammad, J. (2018). Employee Pro-Environmental Behaviour: A Systematic Review and Suggestions for Future Research. The Journal of Social Sciences Research, SPI 2, 272-280. https://doi.org/10.32861/jssr.spi2.272.280

Azmi, N. R. L., Sobri, A. Y., \& Nurabadi, A. (2018). Kepemimpinan Ekologis Kepala Sekolah Dalam Pembentukan Sekolah Berbudaya Lingkungan. Jurnal Administrasi Dan Manajemen Pendidikan, 1(3), 327-336. https://doi.org/10.17977/um027v1i32018p327

Clayton, S., \& Myers, G. (2014). Psikologi Konservasi Memahami dan Meningkatkan Kepedulian Manusia Terhadap Lingkungan (terj). Pustaka Pelajar.
Creswell, J. W. (2018). Penelitian Kualitatif dan Desain Riset Memilih diantara Lima Pendekatan (Ketiga). Pustaka Pelajar.

Efendi, M. H., Irawati, M. H., Rohman, F., \& Gofur, A. (2017). Islamic View of Environmental Conservation Education in Pondok Pesantren Nurul Haramain Lombok Barat-Indonesia. Journal of Education and Practice, 8(12), 137140. http://e-resources.perpusnas.go.id:2105/

Fua, J. La, \& Wekke, I. S. (2017). Islam dan Konservasi: Pendekatan Dakwah dalam Pelestarian Lingkungan. Al-Tahrir: Jurnal Pemikiran Islam, 17(02), 411-432. https://doi.org/10.21154/altahrir.v17i2.998

Goulgouti, A., Plakitsi, A., \& Stylos, G. (2019). Environmental Literacy: Evaluating Knowledge, Affect, and Behavior of Pre-service Teachers in Greece. Interdisciplinary Journal of Environmental and Science Education, 15(1), 19. https://doi.org/10.29333/ijese/6287

Hafida, N., \& Wahid, A. H. (2018). Pembentukan karakter peduli dan berbudaya lingkungan bagi peserta didik di madrasah melalui program adiwiyata. FIKROTUNA: Jurnal Pendidikan Dan Manajemen Islam, 8(2), 950-971. https://doi.org/https://doi.org/https://doi.org/10. 32806/jf.v8i2.3295

Hunter, R. H., \& Jordan, R. C. (2019). The TELA: A New Tool for Assessing Educator Environmental Literacy. Interdisciplinary Journal of Environmental and Science Education, 15(1), 1-9. https://doi.org/10.29333/ijese/6286

Idris, S. (2017). Internalisasi Nilai dalam Pendidikan (Konsep dan Kerangka Pembelajaran dalam Pendidikan Islam) (Susanto (ed.)). Darussalam Publising.

Jatmiko, A. (2016). Pendidikan Berwawasan Ekologi: Realisasi Nilai-Nilai Ekologis dalam Kurikulum Pendidikan Agama Islam. Al-Tadzkiyyah: Jurnal Pendidikan Islam, 7(1), 45-62. http://ejournal.radenintan.ac.id/index.php/tadzki yyah/article/view/767

Landriany, E. (2014). Implementasi Kebijakan Adiwiyata Dalam Upaya Mewujudkan Pendidikan Lingkungan Hidup di SMA Kota Malang. Jurnal Kebijakan Dan Pengembangan Pendidikan, 2(1), 82-88. http://ejournal.umm.ac.id/index.php/jmkpp/artic le/view/1739

Lickona, T. (2015). Mendidik untuk membentuk karakter: bagaimana Sekolah dapat memberikan pendidikan tentang sikap hormat dan bertanggung jawab, Terj. (Cet 4). Bumi Aksara.

Machfutra, E. D., Noor, A., Asropi, Luxiarti, R., \& 
Mutmainah, N. F. (2018). Perilaku Hidup Bersih dan Sehat Santro Putri Pesantren X Yogyakarta. Buletin Penelitian Sistem Kesehatan, 21(4), 236-246.

Muhaimin. (2015). Membangun Kecerdasan Ekologis: model Pendidikan Untuk Peningkatan Kompetensi Ekologis. Alfabeta.

Muntaha. (2019). Ecological Intelligence in 2013 Madrasa Curriculum. 6th International Conference on Community Development (ICCD 2019), 349, 366-368.

Muntaha, Tobroni, Ishomuddin, \& Khozin. (2020). The development of ecological intelligence through "Madrasah" culture. International Journal of Psychosocial Rehabilitation, 24(7). https://doi.org/10.37200/IJPR/V24I7/PR270984

Nuha, U. (2017). Integrasi Pendidikan Agama Islam dan Pendidikan Lingkungan di Pondok Pesantern. GENETIKA Jurnal Tadris Biologi, 1(1), 175-187.

Purwanti, D. (2017). Pendidikan Karakter Peduli Lingkungan dan Implementasinya. Jurnal Riset Pedagogik, 1(2), 14-20.

Rahmat, A., Smith, M. Bin, \& Rahim, M. (2016). Perilaku Hidup Sehat Dan Prestasi Belajar Siswa Sekolah Dasar. Psympathic: Jurnal Ilmiah Psikologi, 2(2), 113-122. https://doi.org/10.15575/psy.v2i2.452

Sanjaya, R., Fara, Y. D., \& Sagita, Y. D. (2019). Perilaku Hidup Bersih dan Sehat (PHBS) di
Sekolah. Jurnal Pengabdian Kepada Masyarakat Ungu ( ABDI KE UNGU) Universitas Aisyah Pringsewu, 1(1), 55-60. https://puskesmasbatuputihberau.wordpress.co $\mathrm{m} /$ promkes/info-kesehatan/perilaku-hidupbersih-dan-sehat-phbs-di-sekolah/

Sugiyono. (2016). Cara Mudah Menyusun Skripsi, Tesis, dan Disertasi. Alfabeta.

Sumantri, A. (2015). Kesehatan Lingkungan (Ketiga). Prenadamedia Group.

Taklimudin, T., \& Saputra, F. (2018). Metode Keteladanan Pendidikan Islam dalam Persfektif Quran. BELAJEA: Jurnal Pendidikan Islam, 3(1), 1. https://doi.org/10.29240/bjpi.v3i1.383

Yin, R. K. (2015). Studi Kasus Desain dan Metode (Edisi Revi). Raja Grafindo Persada.

Yunansah, H., \& Herlambang, Y. T. (2017). Pendidikan Berbasis Ekopedagogik Dalam Menumbuhkan Kesadaran Ekologis Dan Mengembangkan Karakter Siswa Sekolah Dasar. EduHumaniora:Jurnal Pendidikan Dasar, 9(1), 27-34. https://doi.org/10.17509/eh.v9i1.6153

Cite this article as: Muntaha. (2020). Islamic Ecological Culture: Instrumen untuk Membentuk Perilaku Hidup Bersih dan Sehat. Jurnal Ilmiah Media Husada. 9 (2), hal.67-81. https://doi.org/10.33475/jikmh. 